\title{
Understanding Reading Motivation for At-Risk Adolescent Girls
}

\author{
Erin Donovan \\ University of North Carolina, Charlotte
}

\begin{abstract}
The purpose of this study is to understand the relationship between adolescent girls who identify themselves as possessing delinquent characteristics and how that identification corresponds to their reading motivation. Four $8^{\text {th }}$ grade girls were interviewed to ascertain the link between attitude, self, identity building activities, resistance, and reading motivation. Discourse analysis was used to thematically connect these ascribing characteristics. The understanding of this connection is essential to promoting academic achievement in students who act in resistance toward the established authority of the school house culture. This study is framed through a post-modern understanding of transactionalism and demonstrates how, through a blended approach, the concept of transactionalism can be used to understand the interaction between delinquent girls, school authority, and the act of reading.
\end{abstract}

\section{Introduction}

The world of the adolescent girl revolves around identity [20].The contextual consideration of who they are and how others see them works to inform their identity, as it changes moment to moment based on moods, friends, conflicts, successes and failures. The school environment is a prime location where identity puts on its show. Acting out identity for some may include acts of delinquency that show resistance to the authority of the classroom. [16].The purpose of this study is to understand the relationship between adolescent girls who identify themselves as possessing delinquent characteristics and their corresponding reading motivation. The link between attitude, self, identity-building activities and reading motivation is essential to promoting academic achievement in students whose acts of resistance place them in conflict with acceptable periphery of the school culture.

Gendered research in the field of delinquency is in its relative infancy [11]. While there is much work to do to explain how delinquency looks in the female sphere, where it comes from, and its overall effect on both the girl and society, there is still more work to do to understand how that delinquency and the identity created therein impacts reading motivation. Reading motivation in adolescents has been well documented for both the successful student and those who would be labeled at-risk [22]. However the majority of the exploration of those at-risk students has been defined through terms of their socioeconomic and minority status and is measured through standardized testing [4]. Delinquency, on the other hand, is measured through suspension and penal records [17] and the academic affects it may have is often only an afterthought.

The goal of this paper is to find a link between the idea of female adolescent delinquency and reading motivation. Four female $8^{\text {th }}$ graders who label themselves as possessing delinquent behaviors and act in resistance to school authority, were interviewed to understand their constructed identity and how it might influence their reading motivation. Using a blended theoretical approach transactionalism, as it is used to explore behavior [6], and as it applies to the interaction between the reader and the text [14], is used to link delinquency and reading motivation.

This paper has been divided into six sections. Section one of the study highlights the literature used to inform the premise of this paper. Section two outlines and defines the components of the theoretical framework employed. Section three defines the methodology used. Section four provides an analysis of the data found through the interviews. Section five offers a discussion of the data and details the themes that emerged from a discourse analysis of the conversations. Section six concludes the paper through a summary of the basic findings of the work as well as offers suggestions of areas of future research.

\section{Literature Review 2.1 Gender}

Gender is a taught identity construct [22]. The characteristics of being female are loudly painted in a society that seeks to categorize its children as either being a girl or boy. Jones argues that becoming a girl and defining what a girl should be is socially constructed and dictated by the particular context in which that girl exists [19]. Zahn presses the point by emphasizing that "girls today face greater struggles 
in maintaining a sense of self and confronting a complex, often contradictory set of behavioral scripts that specify what is appropriate, acceptable or possible for girls to do" (pg. 51) [17]. Abowitz stresses that the difference between the male and female genders is that girls have greater pressure to adhere to social norms imposed on their appearance and actions. They are defined by their ability to conform or resist these expectations. Thus, regardless of context, a girl's identity kit is equipped by the world she lives in and the role she seeks to emulate or create [13].

Gender roles may be also be dictated by social economic status [16]. Women may have to work harder to be what society claims is feminine if they are also working not only at raising their children but also supporting them financially. Hochschild and Machung highlight the absolute economic reality of working women and their financial support of their family [1]. It is no longer enough to be a strong mother. In many cases, women work as the economic backbone of their family units. These dual roles may lead to a change in traditional gender identities. Femininity might be characterized by strength, power and even defiance. Strong girls or even real girls may be those that fight and engage in delinquent behaviors that shift the power dynamic [13]. Girls may find themselves fighting for or against something urged on by the need to protect themselves, their family, or their honor.

Jones goes so far as to claim that it may be dangerous to be a good girl [13]. On the other hand, a girl embodying the stereotypical visage of femininity or a "good girl" is also a good reader. Being motivated is part of her identity kit. Therefore if it is dangerous to be a good girl it might also be dangerous to be a good reader. This counteracts the traditional gender stereotype of femininity that embraces the idea of being a highly motivated reader [22].

\subsection{Delinquency as an act of resistance}

In preparation for conducting the present study my colleagues and I developed consensus definition of juvenile delinquency. We concentrated on using careful language to include definers, aspects which applied to all cases, rather than descriptors, factors which are important to take into account but those which may not apply to all cases [5]. Our ensuing consensus definition and which stands as the definition for juvenile delinquency maintains that juvenile delinquency is when youth engage in antiauthoritarian action that is framed through socially constructed identities.

Delinquency may be related to resistance. Kim claims that resistance can be used to explain the student behaviors that result due to the tensions and conflicts some students feel as a result of school level authority [12]. Resistance is contextual and works as a part of student created and refined identity kits. Resistance may be expressed in terms of self-defense, as a refusal to learn, or empowerment, seen when students don't feel they are being challenged or receiving appropriate instruction, or may even be evident as a moral imperative [12].

Because schools are traditionally seen as an oppositional force against students, the force against which the students resist, it is the responsibility of the school to control for resistance and the ensuing delinquent behaviors [13]. Howell urges educators to look for predictive factors, especially in females to work towards prevention. Such factors include child abuse, mental health issues, running away, gang involvement, and peer group disputes [11].

\subsection{Labeling}

Students construct their identity through style, action, and behavior to purposely resist the apparent authority the school house possesses [11]. Behaviors, actions, and style work as a platform for the affixation of labels. The labeling theory of delinquency suggests labels can be affixed by others or by the self. The labels can dramatize social interactions exacerbating the me and them or even demonizing the delinquent other without seeking understanding of a child's true self or intentions [10].Adolescents are aware when such labels become attached to them they may make a conscious effort to live up to the identity by which they have been labeled or react strongly against it, thus creating a self-label.

Girls in particular act as active agents constructing their own identity. They may define themselves oppositionally, in relation to their peers, or as a means to resist authority. Regardless, they actively work to construct their social roles [16]. Their identity may very well fall in line with the label the adults have given them. They may exercise their self-knowledge and label themselves according to their own self-definition, thereby proving the adults wrong. Regardless, adolescent girls are far from passive when constructing and labeling the self they want to portray to their peers, family and in their overall social environment.

\subsection{Reading motivation}

Reading is not a set of skills considered mastered by demonstrating competence through answering a selection of multiple choice questions. Rosenblatt argues that reading is about a connection to literature and that its significance comes from the interaction between the reader and the text rather than from their separated states [14]. Thus the quality of a reader's 
experience is not only about the text, but the quality she brings as a reader. Therefore if one is resisting the authority of school and they recognize reading as a school sanctioned experience that may lead to a resistance of a connection to reading, which may impact their motivation. The interaction with literate can be an intensely personal one or it can be an experience shared socially [15]. Because of this variation, the reader must be open to discovering reading through a discovery of the self.

Reading motivation is a broad trait that varies over time and context [9]. It may be as dependent on a student's mood as on their choice of reading material. Motivation may be defined as the authentic desire to read for purposes designated by the reader. This definition can be applied then to school sanctioned reading and that which spans beyond the school house walls. Motivation is personal and when it is real, it is authentic. It is also the foremost indicator for academic success [9].

Students read too little and rarely read deeply [9], but Finders contends that when girls choose to read on their own time, they do so purposefully and for authentic reasons. They read beyond the curriculum creating their own rituals and rules [16].Coddington and Guthre agree that there is a need to understand reading motivation as it applies to attitude and the impact of gender[16]. Affect is then determined by behavior beliefs and outcomes of the behavior, again highly correlated with gender. Thus motivation is tied to how a student sees the outcome of their behavior and if the outcome is negative, reading motivation decreases [4].

It has been well researched that reading motivation is strongly affected by the home environment [4]. As well, peer interactions and perceptions influence reading behaviors [9]. But the strongest predictors of motivation remain attitude and cognitive recognition [4].However Guthrie points out that disengagement from reading starts young and reading is soon relegated to an activity one has to do in language arts class [9]. He suggests increasing motivation through socially constructed activities to escalate student motivation and connection. He also suggests that relevant texts that can take an active role in the students' lives, because, as Finders echoes, when students really read they read for themselves [16].

\section{Theoretical framework}

The theoretical framework of this paper revolves around using the idea of transactionalism to define resistant behavior and literary connection. It is necessary to provide a blended theoretical approach due to the disparate natures of the two variables. Hoffman explains that a theory is simply "an attempt to explain or predict some event or phenomenon" (pg. 7) [10]. Different theories apply to different disciplines. Thus, when more than one discipline is being explored, a blended approach must be taken. This creates a coherence to better illustrate connections or determinations [10].

For the purposes of this paper, resistance is defined as the explanation of the various student behaviors occurring within the school that may indicate the existence of conflicts between the student and authority of the school [12]. It is important to note that this resistance is not two sided (i.e. it is not an us against them paradigm.) Transactionalism then can be used to explain the communicative nature of the behavior's emergence, and growth. Defined by Dewey and Bentley, transactionalism underscores the idea of understanding resistance as the interplay between the actors and the contexts of resistance as a complex act of communication. Through this communication, all parties change and mulit-faceted meanings of situational correspondence are created [6].

Transactionalism is indeed a way of seeing everything all at once and realizing that there is no one truth. As postmodernist theorists note, hegemonic sign posts of the grade narratives must be rejected. The us versus them narrative that so often informs delinquency theories rests upon authority versus subordinates [7]. What follows is the idea of seeing issues and acts not in isolation nor in terms of what is true or not but rather in terms of their contextual points of contact and the changes that result from said interactions [13]. Dewey and Bentley call these moments of contact points of inquiry and it is through these moments of inquiry that resistance can be resolved or at the very least understood [6]. Resistance can then be explained through the transactional points of contact, within a specific context, that changes the organic nature of the interchange between parties.

Transactionalism as described by Louis Rosenblatt revolves around the interaction between the reader and the text [14]. Like Dewey and Bentley's transactionalism, there is no clear delineation between the text and the reader. Rather, it is the interaction that holds meaning and thus inspires motivation. Rosenblatt breaks down a reader's experience between the efferent, describing an analyzing relationship and aesthetic, describing an experiencing relationship. But overall it is reliant upon the contextual power of the reader and the text [15].

Thus the theoretical framework of this paper rests upon an undefined relationship between actions and actors whether they are authority or literature. But each party holds equal importance. It is the interaction between the parties that is essential to understanding how delinquent behaviors as manifested as a result of resistance, link to reading motivation as shown through the interaction between the reader and his or her text. 
The research question of this study, understanding the relationship between adolescent girls who identify themselves as possessing delinquent characteristics and their corresponding reading motivation necessitates a blended theoretical approach. By assessing the transactional nature of resistance as well as reading motivation, it is possible to compare and contrast the forces surrounding both ideas. The idea of transactionalism as it is dualistically defined in the reading and behavior spheres facilitates this comparison.

\section{Methodology}

This study is defined through the application of the analysis of discourse between four students and the researcher. Because the idea that transactionalism works through contextual and communicative instruments, the idea of conversation or discourse should be the appropriate means by which the ideas embedded within the identities of the subjects may be extrapolated.

This study takes place in what Milner terms an urban emergent environment. An urban emergent designation speaks of schools that are located in large cities with problems more typical to urban intensive situations: scarcity of resources, high minority or low socioeconomic populations, and issues of crime for their large populations [21]. Although the problems encountered are significant, they do not require the magnitude of assistance larger cities need. Typically an urban emergent environment is not as densely populated as urban environments.

I chose to pick my sample population from a midsize urban school in the South. Through a flyer advertisement and snowballing, I found a sample of four girls who volunteered their time to be interviewed about their reading motivation and identity characteristics. The girls went through the consent and assent process and passed a prequalifying survey to ensure that they did label themselves as having delinquent characteristics. I then met with each student for approximately twenty minutes to explain the study and answer any questions they might have. The interviews took place after school hours in a remote classroom housed in the school and were audio recorded. Additionally, I also took notes of contextual events to better describe the conversations.

My role is a bit precarious because on one hand I am their teacher and on the other I am the researcher. However, my goal was to create a liminal or third space where the girls could feel safe to talk about sensitive issues and accept me more as a researcher than as their teacher[16] I overemphasized the fact that our interviews could remain between the two of us.
To thematically connect the work, I will use discourse analysis. Discourse analysis is dependent upon spoken exchanges that are reflective of the identity of the speakers as they are mirrored in the contextual understanding [18]. A well done analysis may reveal speakers' roles, identities and relationships through the power of language. Identity as Gee defines it works to include the roles people play, their cultural knowledge and beliefs, their feelings and values, how they build relationships and what is significant in their life [7]. This method then not only reveals the identity of the speakers but also evidences the importance of the conflicts that shape them.

I will make use of the idea of social language to help thematically categorize the conversations. Social languages include styles and varieties of a more formal language. They are most often contextual and may include the jargon or slang of a particular group. Using this concept may reveal social labels, perceptions and roles [6].Social language considers grammar, language patterns, situational meaning, and signals into consideration when thematically coding discourse.

\section{Analysis}

As an educator it has been my evolving goal to understand the students I work with through their constantly changing identity kits. One such student, LeLe, caught my attention early in the year. I was reading Between good and ghetto [19] and LeLe seemed to fit the mold of what a ghetto girl might look and act like. At the time she was very mad at me for making her do her work the day earlier. Her stubborn determination not to talk or look at me intrigued me. I knew she was a struggling student academically and the exterior image she projected at school was unmistakably tough. It made me wonder, which came first, the struggle or the toughness?

So I decided to jump in and said, "I just read a book that reminded me of you." She slyly looked at me out of the corner of her eye, still unwilling to commit to a conversation. "Oh yeah, so what?" she said in her fast moving speech that could be a cutting tool of retaliation. "Well, I just thought you should know. I was thinking about you." She scrunched up her face and I could tell this was not the conversation she expected to have. "Well, I should be in a book. I should be." With that admission, the genesis for this project emerged. LeLe and girls like her should be explored so that educators could more effectively negotiate around their tough exterior to get to the inner reader, who may be struggling, unmotivated, or secretive.

I grouped components of their conversations thematically. I divided them into two major categories-issues associated with delinquency and issues associated with reading. Within each major 
category, I grouped their responses and assigned them labels. Within the reading category, I found the following to hold major thematic importance:

- Experiences as a beginning reader

- School versus home reading

- Reading choices

- Issues with school (generally and with reading in particular)

- Issues with teachers

- Self-image as a reader

Within the delinquency category, I found the following to hold similar weight:

- Self-label/self-image

- The idea of strength

- Gender identity

- Father issues

- Family relationships

- Affixed labels

- Friends

- Acts of resistance

- Visions of the future

- Change

\section{Discussion}

The intention of this project is to speak with girls who identify themselves as enacting delinquent behaviors. In doing so, I was trying to find girls that "fit a mold" or conformed to my stereotype. When I reflect on the purpose of this paper and the girls I came to know, I realized this was my first mistake. The girls came to me wanting to talk about their lives but I admit when I looked at them, I assessed them through behavior and appearance labeling theories, wondering how well they would fit the image I was looking to depict through this project. The first thing I learned is how little they fit my prearranged ideals. Using the idea of transactionalism, where we speak contextually as equals, trying to figure out a common understanding of an idea or an event, helped me begin to understand the complexity of these girls I was initially so quick to pigeon hole.

The interviews always began with each girl choosing her pseudonym. I was surprised how important this activity was. Ariel had her name chosen without a second thought. It was as though she had waited her whole life for someone to ask her who she really was and what she really wanted to be called. Susi on the other had left it up to me and seemed very happy when I branded her with her new name. In fact, in the letters she continues to write me and whenever she is having a bad day, she addressed herself as Susi. LeLe chose to go by her nickname and Ivy seemed find her secret identity that she might call herself if she needed to be particularly cunning.

I asked each girl first about her self-image. In the cozy classroom with the air conditioner humming beside us, Susi leaned forward and spoke clearly into the recording I-pad when she answered. She had her hair tied up in a bandana and her long pearls clinked on the desk as she talked. "I'm like.. I used to have a lot of anger built up inside of me. I can be a very nice girl and at times I can be a very mean girl." Lele started her interview out defensively trying to redefine the person she was sure I had her pegged as being. She was wearing her signature black leather jacket. Her long white nails that she had done just a week earlier seemed to help articulate each of her points. "I'm not ghetto. Like I'm very chill, nice, um funny person. Some people that know me think I'm cool, funny, all that type of stuff. I see myself as an independent girl because I don't follow what anyone else do. I just do my own thing."

Ivy sat in front of me with her high cheek bones, and statuesque posture. She seemed to dress to accentuate her thin frame and did so with style that showed she had carefully considered exactly what she was going to wear and how well it matched. She answered, "But I'm nice, in my opinion. I'm nice. I like to help people out a lot, even though I'm mean sometimes and I just like tell people stuff to help them but some people don't like that."

Ariel stood out in the group. She was petite and that afternoon, very calm. She had just dyed her hair screaming red and her hands were still stained from the self-applied color. You could tell she was dying for my opinion of what she had done. She was wearing an outfit that was a little punk and a little girly and the plastic retainer that was keeping her teeth straight clicked as she talked through her answers. "I'm different, well I don't know. I can sometimes be loud and outgoing and other times be really quiet and to myself. I like my crazy hair colors." At this point I agreed that I liked them too.

Each girl protested regarding how she felt she had been labeled. Although they admitted that they had done things that may have prompted those labels, most claimed that if people tried to get to know them or really understood them, their opinions would change. Susi started. "People see me like a tough girl like a few people, they know the real me on the inside and teachers who actually sit down and talk, but all the other see this tough girl. Oh she don't care, oh she can fight and all this. No, that's not me at all. You got to really sit down and know the real me." Again LeLe was defensive in her answer. "People see me as a ghetto person not a mean person but a ghetto person. Everybody think that I am a fighter because I speak my mind just because I don't hold a lot of stuff in." Ivy agreed and found a way to place blame. "People call me mean but because I got a bad attitude. Last year there was nothing but drama on my hallway. When I get with people who get on my nerves well I know I really be getting in trouble." Ariel's answer was tinged with much more hurt. She had been through a bullying experience in $6^{\text {th }}$ grade 
that was so severe, she had to leave school. The labels she perceives were influenced by that incident. "They think I am little weird. I know that. I know that people talk about me a lot and oh well. I know. I have heard negative stuff and that I am crazy, but then I also hear that I am outgoing so you know."

Across the sample, none of the girls seemed to have any close friends, and they seemed to prefer it that way. "I don't have many because you can't trust everybody." (Susi) "I wouldn't say close, but I would say associates. I wouldn't stand up for your friends because it's not your battle, it's her battle, if your friend get in drama or she get in a fight you don't have to jump in it." (LeLe) Ariel had the most to say on this subject and as she talked, a recent sting was evident in her tone. "I don't like too many people. They just annoy me. They get on my nerves and so I just don't like talking to them and um people I like are nice, not too judgmental you know, different, like me. Someone I can talk to. I have really big trust issues." Later in the interview she went back to this issue of friends as she talked about recent trouble she had been having. "I had one friend that I stopped being friends with because the friendship was behind closed doors. She still tries talking to me and I'm just like no. I just try to do things so that she leaves me alone. I'm just like, you chose popularity, you wanted to keep your popularity level up by not hanging out with me by not like.. She takes photos with other people and puts them on Facebook. Me? Nowhere."

The other issue they had in common was fathers. Each girl I interviewed was estranged from or missing a father in her life. Susi said it best. "As a girl you want many things but your mom can't get it. So as a girl you want your dad in your life. You need him to be there and say baby it's ok and help you get things so you don't have to feel so responsible for taking care of your moms." Lele wouldn't look me in the eye when she said she didn't know her father and Ivy was so matter of fact about her missing father, it was as though she never needed him anyway. But when she talked about her brothers there was a tenderness that revealed her hidden emotions. "All of them, my older brothers are aggravating but (laughing) but I love em. I love my brothers."

Gender was one area that was tinged with frustration. It was obvious that being a girl, while worrying exactly what that was supposed to mean and what that was supposed to look like, added a layer of confusion to their lives. Susi spoke with frustration regarding the symbols of gender she couldn't afford. "As a girl, I want those things. You know how some of them dress. They dress fancy. I be wanting to get some of that stuff but my mama be like I can't get it now. I get clothes from my big cousin and I really don't mind 'cause she dress nice, but then again I want my own. I don't always want your hand me downs." LeLe echoed this concern. "You have to look a certain way. It's like ok, I'm a girl. I get up and my hair be looking all wild and I start getting frustrated like ok, what am I going to do with my hair? And I put it in a ponytail and then I try this and it don't look right and then I get all sad. I just think it's hard for a girl because you come to school and people be like those are fake Jordans, or oh you don't match. I wonder if I was a boy how would I look? I think I would look cute and it would be easier."

The girls as a group seemed to agree with some overall ideas. They identified themselves differently than others did and this misunderstanding often caused resistant behaviors that only solidified their affixed labels. They had issues with absent fathers but most had strong relationship with their mothers. Friends were hard to make and all seemed to harbor over-reaching issues of trust. They struggled with their gender identities and most wished for gendered symbols to help prove to others and perhaps to themselves that they were "girly".

However when reading motivation was assessed, their answers widely varied. Their responses could be categorized thematically but in order to understand their answers each particular girl must be considered as an individual. As much as they were labeled by their resistant behaviors, they seemed lost as students. It was as if school had much more to do with their resistance than it had to do with reading.

LeLe claimed to always do her work, but her grades showed a struggling student. She performed poorly on end of the year exams and struggled as a reader. She does not read at school and does not read at home. When I asked her what her major problem with reading was, she answered firmly as if she had diagnosed her problem years ago. "As a reader, I'm in the middle - not the best and not the worst cause of the big words I don't know. If someone taught me those big words I would love to read. I would be like the biggest reading person ever. I would say a big word and I would be like, yeah I know that word." Aside from increasing her vocabulary she noted that, "I don't like to read, but I like to read like something that entertains me. If it's like a boring book I won't read it. I like something with drama in it."

Susi on the other hand is what most of her teachers consider a good student. She is in honors language arts and does well in math. However, historically she was not a motivated reader. "I used to hate reading. You give me a book and I will push it over. I would not read it, but then I realized that going through school you need to read, it's your everything in school." She described another change in her reading behavior. "I went to summer school. There was this book. It's called The skin I'm in and I picked up that book and I was like oh, this looks good and like it could kind of connect with me. We 
was reading and ever since then, at the end of summer, they give us all the books. So ever since then I have a lot of books. I read them all but now I need new books." Similar to LeLe needing to be entertained through reading, Susi needed a strong connection to what she was reading in order to truly count herself as a motivated reader.

Initially, Ivy had very little to say about her reading. She counted books that related to her as books she would like to read. She had far more to say about teachers who frustrated her. She spoke out about the idea of having her time wasted and not learning enough to prepare her for high school. Beneath her guarded persona, I uncovered a very capable reader who was motivated to read each night at home and sought out opportunities in the tutoring program held in her neighborhood. "I read all the time at home, like before I go to sleep. I read like 30 or 45 minutes every night and I read at tutoring in my neighborhood." She reads books she connects to and proudly told me about several series she read from beginning to the end.

Ariel was the exception to the group. Where the other girls wouldn't carry a book with them around school, Ariel was never without one. She counted reading as her escape and excitedly tried to convince me to read the book she just finished. "I mean yeah I like reading but like other people are like oh that's not cool but I really don't care. I like it like when teachers aren't here. I end up reading the whole time and doing the work at home because then it's just easier because then people aren't asking me questions the whole time." Ariel counted herself as one of the smartest students in the class and like Ivy often found herself exasperated with the remedial nature of her classes. "I'm not challenged at all. I get so bored I just stop doing the work that I don't want to do." Ariel is the one student who uses reading, with books of her own choice and at her own time, as an act of resistance.

\section{Unpacking the myths}

As I went through the interview process with the girls I was struck by how misunderstood they were. When I think about the myth, that the girls love to fight, I am reminded how hesitantly the girls do fight and how when they do it is because for many of them, they have reached their boiling point. Susi described a recent fight she was involved in. "I was already nervous got to get my tooth pulled and everyone says it hurt all this stuff running through my head and my mama stressed not knowing what to do. Then he said something and all of it just come out and I exploded and pop, it was just so much." This showed that fighting is a reactionary behavior for Susi rather than a planned activity. LeLe also fights as a reaction to the environment around her. "When people get you p-ed off it make you want to have an anger spasm. I get mad quickly. I can say one word and get mad. It gets me mad when people are aggravating me when people tap you and say LeLe, LeLe. Sometimes I just can't control what happens next."

The cultural myths idea of having a tough appearance and exhibiting male behavior were also proved false by the girls' words. They all spoke of their appearance but none of them specifically constructed a tough appearance. "I'm kinda a girly girl but in a tom boyish way like I have my chill day or my hype day."(LeLe) Susi used the word "tough" in the context of its misuse. "I try to be tough but I'm not that tough. I just have a lot of anger that's needing to be out. You have to put up with a guard." Ariel constructed her image through her outrageous hair colors which scream for attention, but the idea of looking tough never surfaced in our conversations. As well, none of the girls spoke about displaying male characteristics. If anything, the girls in my study, albeit perhaps a bit atypical, displayed what I would consider overt symbols of femininity. As a group, they spend countless hours matching their outfits and doing their hair. They discussed the frustration of wanting symbols to more nearly embody the image of what a female is, as ascribed by the prevailing culture.

The phrase "ring leaders" also surfaced in the literature dealing with delinquency. To me, that has a negative connotation. When the girls mentioned their status at school, they spoke of being a leader with pride and something to be admired. "I think people would say that I am a leader. It's not like I have followers or nothing but when people see me they know me. They do what I do. I don't think that's bad except you know when I did bad things, then I be like, I wish they would see what I do good and follow that." (Ivy) Ariel pointed out her leadership role in the classroom as others asked her for help. "See, like the other day in math, this girl needed help and you know everyone comes to me because I like have been doing this since I was like five and she got it. Even the teacher couldn't make her understand but I could."

One that is highly reported in the literature is that delinquent girls are loud and disruptive. They are loud. They speak their mind and struggle to hold their tongues. But I think this is what makes them strong. They roar against the constructs of society and school while reaching out to the people around them, crying for attention and respect. It is this volume, if harnessed, could make for a truly engaging classroom. How amazing would it be to channel this loud energy into a culturally responsive discussion about the crimes of the world both in and out of the classroom? 


\section{Limitations and future research}

As noted, there is much work to be done with girls and their patterns of delinquency let alone the link it might suppose with reading motivation. This paper seeks to find a link between reading motivation and delinquent behaviors in girls but as there were only four participants interviewed, the results cannot be generalized. However, the thematic ideas uncovered through discourse analysis opens the door to other studies that might help educators understand how to link these two ideas to better serve their students.

While I was collecting my sample of girls and explaining the project to them, one or two boys overheard. They were quite vexed that they were not to be included in this study. They point blank asked what makes girls so special! Of course the next step in the application of this research paradigm is to interview boys to compare both their patterns of selflabeling as well as their attitudes toward reading motivation.

\section{Conclusions}

The purpose of this study was to examine the link between female delinquency and reading motivation. Four $8^{\text {th }}$ grade girls were interviewed and those conversations were thematically categorized through discourse analysis. It was the intention of the study to seek an understanding of that link that might be applied to increase reading motivation while decreasing behaviors of resistance.

What I found were four girls just waiting for someone to listen to their story. They were misunderstood and mislabeled. However these girls, even for their youth, knew themselves. They understood the roots of their delinquency and clearly saw the negative impacts of their decisions. They all recognized the need to change and upheld the importance of education. Overall school seemed to be a place they wanted to go to and although the pull of seeing their "associates" certainly drove this, they citied their frustration when they didn't see learning occurring.

As readers, individually they were disparate as far as ability and history but there was apparent motivation within each girl. For most of them, however, it was not a motivation that was compatible with their image at school. They each knew what they liked to read and why. As Rosenblatt (1963) theorizes, it is the transactional moment between the reader and the book. That connection yields the ability to visualize the narrative and that makes reading a significant activity, one that Ivy pursued with pride as she talked with me, even as she admitted she would never carry a book down the hall.

My recommendations for educators are twofold. The first deals with resistance. Girls who evidence resistant behaviors may be doing so because they have been pushed too far. When the teacher is only one in the series of fingers that have been waved in their face, she will be the one that gets told off. It is not constructive to talk at or to these girls. Rather, one should talk with them. Encourage activities in the classroom that provide space for discussion and self-awareness. It is essential to remember not to push a girl when she is already in a corner. One should provide space for her to make the right decision. The girls interviewed not only understood their behaviors but they also knew how to fix them, if only given the space.

The second set of recommendations regard reading motivation. Educators should challenge the purpose of their classroom. Readers want to read stories about people who look like them, who they can connect to. They want to experience that transactional moment where reading becomes meaningful, entertaining, and maybe even inspirational. Forcing them into reading contracts where they can't switch books or provide a list of teacher approved books does not lend itself to the creation of a transactional moment. Again the idea of space reappears. Allow readers space to read themselves into a book and they will start reading. Open up that space to talk, and they will start talking. Soon, you will have girls who are learning, growing and achieving. Ivy reminds us how simple it can be. "I wish I was reading something interesting."

\section{References}

[1]A. Hochschild, A. Machung, A.Second shift. New York, NY: 1989.

[2] C. Coddington, J. Guthrie. "Teacher and student perception of boys' and girls' reading motivation", Reading Psychology, 30, 2009, 225-249.

[3] D. Gottfredson. Schools and delinquency.UK: Cambridge University Press, 2001.

[4] E. Schooten, K. Glopper, R. Stoel, R. “ Development of attitude toward reading adolescent literature and literary reading behavior", Poetics, 2012, 32, 343-386.

[5] F. Esbensen, C. Maxson. Youth gangs and international perspective. New York: Springer, 2011.

[6] J. Dewey, A. Bentley. Knowing and Known. New York, NY: Greenwood Press, 1975.

[7] J. Gee. An introduction to discourse analysis theory and method. New York, NY: Routledge Press, 1999.

[8] J. Gee. How to do discourse analysis: A toolkit. New York, NY: Routledge Press, 2011.

[9] J. Guthrie. Engaging adolescents in reading. CA: Corwin Press, 2008. 
[10] J. Hoffmann. Delinquency theories: Appraisals and applications. NY: Routledge Press, 2011.

[11] J. Howell. Preventing and reducing juvenile delinquency. San Deigo, CA: Sage Press, 2003.

[12] J. Kim. "Understanding student resistance as a communicative act. Ethnography and Education", 5(3), 2010, 261-276.

[13] K. Abowitz,(2000). "A pragmatist revisioning of resistance theory" American Educational Research Journal, 37(4),2000, 877-907.

[14] L. Rosenblatt. "The transactional theory: Against dualisms", College English, 55(4), 1993, 377-386.

[15] L. Rosenblatt. "Literature: The reader's role", The English Journal, 49(5), 1960, 304-316.

[16] M. Finders. Just girls: Hidden literacies and life in junior high. New York, NY: Teachers College Press, 1997.

[17]M. Zahn, M. The delinquent girl. PA: Temple, 2009.

[18] N. Duke, M. Mallette. Literacy research methodologies: Second edition. New York, NY: Guilford Press, 2011R.

[19] N. Jones. Between good and ghetto: African American girls and inner city violence. NJ: Rutgers Press, 2010.

[20] R. Boomer. Girls, social class and literacy: How teachers can make a difference. NH: Heinemann, 2004.

[21] R. Milner. But what is urban education? Urban Education, 47, 2012, 556-563.

[22] S. McGeown, H. Goodwin, N. Henderson. "Gender differences in reading motivation: Does sex or gender identity provide a better account?" Journal of Research in Reading, 35(3), 2012, 328-336. 